\title{
O hábito da pesquisa científica nas faculdades de Direito norte-americanas
}

\author{
Laura Martins Miller ${ }^{1}$
}

Durante o primeiro semestre do ano de 2004, cursei cinco cadeiras da faculdade de Direito da Pace University of New York como bolsista do convênio estabelecido entre a FIPSE e a CAPES. Os desafios apresentados durante a experiência acadêmica variaram desde a investigação do significado de termos jurídicos do common law, cujo equivalente inexiste no sistema romano-germânico, até a argumentação oral na simulação de um julgamento, no qual a atuação de cada aluno era cuidadosamente avaliada e criticada pelo professor da disciplina. Diante deste novo universo, o domínio das fontes de pesquisa disponíveis na faculdade de Direito da Pace University figurou-se como elemento indispensável para lograr êxito nos estudos.

A valorização da pesquisa cientifica nas faculdades norte-americanas pode ser explicada pela utilização do método socrático de aprendizagem. Esta metodologia de ensino baseiarse nas discussóes interativas entre professor e alunos sobre o conteúdo previamente estabelecido para a aula. Neste contexto, a pesquisa auxilia a compreensão dos casos judiciais para preparar as discussões sobre princípios e regras gerais que os fundamentam. Ela também eleva o nivel da interatividade existente entre professor e aluno porque permite que este agregue elementos novos às aulas, além dos constantes nas leituras obrigatórias. De fato, a pesquisa ainda auxilia o desenvolvimento da habilidade da argumentação, que começa a ser estimulada já nos primeiros dias do curso de Direito com perguntas dirigidas individualmente aos alunos pelo professor, visando a estimular a participação em aula e a habilidade com a metodologia.

De regra, os alunos das faculdades de Direito dos Estados Unidos são muito mais competitivos do que os brasileiros. Assim, o aluno pesquisador possui manifesta vantagem em relação àquele que se restringe às leituras obrigatórias

\footnotetext{
- Acadêmica de Direito da Universidade Federal do Rio Grande do Sul. Pesquisadora do grupo de pesquisa "CNPq-Mercosul e Direito do Consumidor", orientado pela Profa. Dra. Claudia Lima Marques. Ex-bolsista FIPSE/CAPES participante do Consorcio em Educação Superior Brasill EUA "Responsabilidade Ambiental: O Futuro do Principio da Precaução e dá Regulação no Brasil e nos Estados Unidos" na Pace University of New York School of Law, durante o primeiro semestre de 2004
} 
recomendadas para as aulas. Além de mais bem avaliado em sua participação em aula, ele consegue estabelecer relações e analogias entre a sua pesquisa e o conteúdo da disciplina no exame final, o que, provavelmente, passará despercebido para o "aluno padrão". Por exemplo, todas as cadeiras que cursei na Pace Law School eram relacionadas ao Direito Ambiental norte-americano, cuja legislação, em geral, exige prévios conhecimentos técnicos para a sua perfeita compreensão, dada a própria característica da multidisciplinariedade deste ramo jurídico. Logo, o aluno que associasse conhecimentos da biologia ou da engenharia ambiental nas discussões de aula ou no exame tinha maior chances de obter melhor nota do que aquele que se restringisse às questóes legais. Neste ponto, as aulas do professor Nicholas Robinson revelaram-se particularmente impressionantes. A cada encontro, uma visão abrangente do meio ambiente, muito além da jurídica, nos era ensinada. Nas suas explicações, o professor nos transportava mentalmente para a natureza do Rio Hudson, por exempto, a fim de explicar os fundamentos das famosas açóes judiciais intentadas contra grande empresa poluidora, as quais resultaram na consciência ambiental da necessidade da preservação dos ecossistemas nos Estados Unidos da América e na posterior legislação asseguradora. A excelência deste professor na área e a sua visível paixăo pela ciência ambiental estimulava os alunos a trazerem novos elementos para as discussöes, as quais, certas vezes, terminavam na biblioteca com a pesquisa dos temas debatidos.

Assim é que o tradicional local de pesquisa continua sendo as bibliotecas das faculdades de Direito. A da Pace University of New York School of Law, por exemplo, contém cinco andares com prateleiras de livros e dois andares com salas e espaços para leitura. Ela é especialmente famosa por sua coleção na área de Direito Ambiental, já que considerada a terceira melhor Faculdade de Direito dos Estados Unidos neste campo. ${ }^{2}$

Com o avanço dos recursos eletrônicos e especialmente da Internet, o meio eletrônico tornou-se também importante fonte de pesquisa nas faculdades. Uma cena comum na bibloteca da Pace University School of Law eram alunos acessando a Internet em seus notebooks em vez de recorrer às pratelerias de livros para a pesquisa. De fato, alunos e bacharéis em Direito tornaram-se verdadeiros aficionados nos dois principais sites de pesquisa juridica na internet: Westlaw (http:// www.westlaw.com) e Lexis Nexis (http://www.lexis.com). Conhecer os seus recursos é tarefa imprescindível para o estudante de Direito nos Estados Unidos da América, motivo pelo qual, a cada início de semestre, são oferecidas aulas para aqueles que desejam aprender a sua utilização.

As razóes da popularidade destes dois sites consistem na sua facilidade de acesso e na ampla base de dados que oferecem. Para acessá-los, o estudante precisa

\footnotetext{
"US News \& World Report's "Americas' best graduate schools 2005" survey. Disponivel em http:t I www, usnews.com
} 
de uma senha, que é fornecida pela própria Faculdade. Esta se responsabiliza pelo pagamento da assinatura dos sites para o benefício dos seus alunos, que navegam de qualquer computador e podem imprimir materiais de graça nas dependências da faculdade de Direito.

Porém, a maior vantagem da utilização destes endereços eletrônicos reside na sua abrangente base de dados. Em vez de recorrer a sites específicos para obter as decisóes de tribunais estaduais, federais e superiores - como fazemos no Brasil - é possivel obtê-las em uma única pesquisa no Westlaw ou Lexis. Basta selecionar $o(s)$ tribunal(is) e, no campo apropriado, colocar as palavras, a citação do caso judicial ou outras referências, como o nome das partes ou o do julgador. A decisão virá acompanhada de indicações sobre a sua adesăo por outros tribunais, algumas definiçōes terminológicas e links para a verificação de decisões correlatas.

Além de acessar qualquer decisão do território norte-americano em único endereço eletrônico, estes sites também possibilitam a pesquisa doutrinária nos mais importantes periódicos jurídicos dos Estados Unidos. Para isto, basta selecionar a fonte de pesquisa e colocar as palavras, conectores, período da publicação ou mesmo a citação completa do artigo. Este recurso toma a pesquisa mais fácil, rápida e eficiente do que checar o artigo no catálogo eletrônico da biblioteca para, então, procurá-lo nas prateleiras.

Outrossim, vale mencionar que estes sites são um meio de comunicação entre os alunos e professores. Ao cadastrar-se, o aluno pode registrar as cadeiras que cursa na faculdade e, assim, averiguar as leituras obrigatórias de cada aula, os avisos do professor respectivo, o endereço de email dos colegas etc. Enfim, tratase de mais uma importante fonte de interação professor/alunos.

Noutro quadrante, os professores também exercem papel relevante no incentivo à pesquisa científica nas faculdades. Muitos professores da Pace University, assim como das demais faculdades de Direito, dedicam-se exclusivamente às atividades acadêmicas. Assim, todos possuem o seu escritório dentro da faculdade e disponibilizam horas do seu dia ao atendimento individual de alunos (as chamadas "office hours") para esclarecer dúvidas, discutir o conteúdo ou corrigir os trabalhos na presença do estudante. Eles também oferecem bolsas para alunos assistentes, as quais são muito disputadas, conjuntamente com as bolsas oferecidas para trabalhar na biblioteca. A disputa deve-se ao fato de que a maioria dos alunos dedica-se unicamente à faculdade, devido à enorme carga de estudo exigida pelo curso. Logo, tais bolsas significam uma possibilidade de ajuda financeira, sem prejuízo dos compromissos acadêmicos.

A própria faculdade promove, anualmente, competiçóes entre os alunos para a publicação de artigos científicos na Revista de Direito Ambiental ou na de Direito Intemacional da Pace Law School. O aluno submete o artigo a uma banca examinadora composta por professores especializados ná área, os quais decidem os artigos publicáveis. Da mesma forma, os melhores trabalhos destinados à 
avaliaçăo das cadeiras também podem ser indicados pelo respectivo professor da disciplina para submissão à banca que os examinará.

Todos estes aspectos da estrutura acadêmica oferecida pela faculdade de Direito da Pace University acabam por habituar os seus estudantes à pesquisa científica devido ao relevante papel que a mesma exerce para o sucesso profissional. Neste sentido, algumas destas idéias já se encontram em franca execução no Brasil, como o oferecimento de bolsas de iniciação científica aos alunos. Outras, contudo, poderiam ser aproveitadas e/ou adaptadas para a maior qualificação do graduando brasileiro, cabendo a nós, estudantes, a iniciativa de, pelo menos, discuti-las e, quem sabe, contribuir para a sua implementação efetiva.

$\mathrm{Na}$ esteira do que mencionei neste pequeno relato, o mérito do Convênio FIPSE/CAPES não está em tão somente qualificar estudantes para o futuro do nosso país. Este Convênio está investindo na perpetuação da pesquisa científica porque forma graduandos desde então compromissados com o seu desenvolvimento.

Em especial, agradeço esta valiosa oportunidade à CAPES, à Profa. Dra. Claudia Lima Marques e ao Prof. Dr. Cezar Saldanha de Souza Júnior, coordenadores brasileiros do Convênio na UFRGS, e, por fim, à Profa. Catherine Tinker, da Pace University of New York, pela sua atenção com os estudantes brasileiros e a sua disponibilidade em contribuir para a continuidade do Convênio. 